\title{
The Accountability of Corporate Social Responsibility (CSR) on Corporate Sustainability
}

\author{
Alexander Phuk Tjilen ${ }^{1 *}$, Fenty Manuhutu ${ }^{2}$, Hubertus Hoja ${ }^{1}$ \\ ${ }^{1}$ Faculty of Social and Political Sciences, Universitas Musamus, Merauke, Indonesia \\ ${ }^{2}$ Faculty of economy and business Universitas Musamus, Merauke, Indonesia
}

\begin{abstract}
The paper underscores the varying and conflicting interests of local community, local government and corporate interest; how CSR implement should comply with the regulation sets by the Indonesia government or fulfill local community needs in aim to gain more favor. This paper aims to analyze the process of formulating the model, the form of execution and the synchronization the implementation of CSR, method used in this research is qualitative, with a case study on PT. Dwikarya Reksa Abadi , Wanam District, Merauke Papua Indonesia. This paper reviews the existing CSR implementation in Merauke Papua with objective of identifying gaps and developing a framework to guide the future CSR implementation. The results showed that the company PT. Dwikarya Reksa Abadi, has implemented CSR to the local community and local economic development around the company as planned but has not received support from labor and community for a conducive business climate, and there are still CSR activities that must be implemented to fulfill local community needs.
\end{abstract}

Keywords: CSR On UU No. 40 2007, Local Communities, Empowerment, Business Climate, Sustainability

\section{Introduction}

The purpose of a company is to generate profits for owners of capital and be responsible for corporate sustainability; which means the company will live for an unspecified period of time, and accountability of CSR gives a role to government and society to be able to assess the performance of the management thus, accountability should be understood as corporate social control[1] (Carmen. 2005) for which their CSR activities have been extensively analyzed in theoretical and empirical research that the definition of CSR entails both self-interest and societal interest, it is natural for the firm to pursue continued growth in terms of economic returns of their social and environmental investment as a primary goal[2] (Soo \& Greenwood. 2017) and CSR can help companies to understand the realization of their role in global economic and financial stability[3] (Roberta \& Menichini. 2013).

One fact remains that the skepticism or suspicion of CSR motives is closely linked to perceptions of corporate hypocrisy[4] (Shim \& Yang. 2016), but it is undeniable "CSR is a kind of real option. As a real option, CSR projects provide a way of reducing the downside business risk of the field and are thus an essential element in the risk management of the corporation" said Husted (2005)[5], all of which have been regulated by the Republic of Indonesia, which regulates social responsibility. The concept of sustainability is meant for how society oversees the implementation of CSR, but focuses on these concepts have provided the society with means for choosing their companies and sanctioning corporate failure, so that the public has the interest to keep companies alive and adding value to the welfare of society[1] (Carmen. 2005).

The increasing needs for CSR sustainability are the result of the environmental degradation, it is a major causal factor in enhancing and perpetuating poverty, particularly among the rural poor when such degradation impacts soil fertility, quantity, and quality of water, air quality, forests, wildlife and fisheries[6](Sendil. 2015).

To meet these needs, the Government of the Republic of Indonesia has applied the Law on Investment (UUPM) number 25 Year 2007, which introduces corporate responsibility to the community, known as Corporate Social Responsibility (CSR), which is the social duty of the organization through advancement programs that give positive incentive through exercises that specifically influence the social

\footnotetext{
* Corresponding author: alexander@unmus.ac.id
} 
existence of the group and additionally nature around the organization.

The enactment on social obligation is talked about in Law Number 40 the Year 2007 with respect to Limited Liability Company (hereinafter alluded to as UU PT) and its executing control in particular Government Regulation Number 47 the Year 2012 on Social and Environmental Responsibility of Limited Liability Company. It is in this context that CSR activities become a mandatory menu for the company, beyond the obligation outlined by the law, corporate social responsibility is a concept under which the company should behave in everyday business decisions and creation of strategy to employees, suppliers, customers, shareholders and other stakeholders[7](Stefanikovaa \& Rypakovaa. 2015).

The actual condition of the implementation of CSR run by PT Dwikarya Semesta, as a company engaged in Fishing and Export Fish operating in Merauke District, is run based on business considerations to implement a proper CSR policy. "The implementation of CSR is still seen as the fulfillment of needs only on the interests of shareholders' satisfaction (high productivity, large profits, high stock value) and personal achievement, so it is still a CSR policy as a voluntary activity"8 (Tjilen. 2012)

\section{Methodology}

The research method used is descriptive qualitative, with direct interview data of respondents of 10 people from internal company, local society and from government staff and district employees. Other data sources are from company files and related research.

\section{Discussion}

The enactment on social obligation is talked about in Law Number 40 Year 2007 with respect to Limited Liability Company (hereinafter alluded to as UU PT) and its executing control in particular Government Regulation Number 47 Year 2012 on Social and Environmental Responsibility of Limited Liability Company

Under the PT Law, the control concerning CSR avows that the organization directing its business exercises in the field as well as identified with regular assets is obliged to complete the Social and Environmental Responsibility, in which the commitment is planned and computed as the cost of the organization whose execution is done with due consideration regarding the respectability and decency.

This is in line with the opinion of Mourougan[8] (Tjilen. 2012) and it cannot be denied that the company that runs CSR, based on the view that the CSR approach is a voluntary commitment[9] (Tjilen. 2015), but regulation will be a force for companies to run CSR in accordance with government target.

Furthermore, in the aforementioned explanation of the article also affirms the purpose of enacting the obligations of CSR is "to keep on creating an agreeable, adjusted and amicable corporate association with nature, qualities, standards, and culture of the group".

The government also issued Law Number 25 Year 2007 on Investment (PMA/PMDN) requires every investment to carry out activities that require the obligation to prioritize the workforce of Indonesia, increase the competence of workers and carry out social responsibility, which supports the implementation of good CSR by domestic investors and foreign investors who do business in the territory of the Republic of Indonesia.

The synchronization of the interests of the state, the interests of the local community and the program essentially reduces Indonesia's competitiveness in the eyes of foreign investors, since in spite of the fact that these directions will cause extra costs that can possibly make the venture atmosphere ugly, part in the execution of the activities or strategies for groups. At the point when there is a need to set exchange offs and the execution of CSR can't be isolated from the commitments of nearby governments, so the commitment of neighborhood governments ought to be boosted and the organization can be a scaffold of advancement for the group.

The logical consequence of the very complex needs of the community certainly becomes an obstacle for companies in implementing the concept of CSR as expected by the community and other stakeholders. Obstacles experienced by companies in implementing CSR are divided into 2 major parts, namely internal barriers, and external barriers. Internal obstacles lie in the limited funds to implement CSR programs, while external obstacles base in relationships with communities and local government.

External obstacles that come from the community that occurred due to community expectations that there will be economic improvements for local communities and increased employment, for that purpose "human resources is fundamental to utilizing natural resources utilization"[8] (Tjilen. 2012), thus the program CSR should be focused on empowerment with a focus on training and mentoring so that people are able to harness the abundant potential of nature, and thus "empowerment can also reinforce aggregate where those with greater power have far more influence than the rest"[10] (Menguc \& Ozanne. 2005), which with this understanding can increase the value of the company and is feasible to be supported by the government and society.

\section{Conclusions}

The implementation of CSR should be based on the basic needs of local people who cannot be separated from the culture of the people of Papua, therefore more aimed at the planning of the CSR program plan, for the economic field in focusing on the empowerment of local communities that are considered useful for the 
community. Implementation of CSR that is based on the government's interest in order that existing corporations in Indonesia should prioritize the use of domestic products and increase the number of local workers. The use of export goods is in line with the government's intention that corporations are also obliged to improve the economy of a region.

\section{References}

1. V. Carmen, Corporate Social Responsibility and Corporate Citizenship: Towards Corporate Accountability, business and society review, Vol. 110, (2005).

2. L. J. Soo and C. A. Greenwood, communicating corporate social responsibility (CSR):

Stakeholder responsiveness and engagement strategy to achieve CSR goals, (2017).

3. C. Roberta and T. Menichini, A multidimensional approach for CSR assessment: The importance of the stakeholder perception journal, (2013).

4. K. Shim, \& S. U. Yang, The effect of bad reputation: The occurrence of crisis, corporate social responsibility, and perceptions of hypocrisy and attitudes toward a company, Public Relations Review, 42, 68-78 (2016).
5. H. Bryan W, Risk Management, Real Option, and Corporate Social Responsibility, (2005).

6. M. Sendil, Corporate Social Responsibility for sustainable business, IOSR Journal of Business and Management. Vol. 17, Issue 5.Ver. I (2015).

7. M. Katarina, L. Stefanikovaa, and M. Rypakovaa, CSR reporting as an important tool of CSR communication, 4th World Conference on Business, Economics and Management, WCBEM (2015).

8. A. P. Tjilen, Evaluasi Program Corporate Sosial Responsibility, (2012).

9. A. P. Tjilen, Implementation of the Economic Program Empowerment of Local Communities in Sota District, Merauke Sub District, Vol. 4 (2015).

10. B. Menguc, \& L. K. Ozanne, Challenges of the 'green imperative': a natural resource-based approach to the environmental orientationbusiness performance relationship, 58(4), 430438 (2005).

11. S. Saegaert, Building civic capacity in urban neighborhoods: an empirically grounded anatomy, 28(3):275-94 (2006). 